University of Rhode Island

DigitalCommons@URI

Civil \& Environmental Engineering Faculty

Publications

Civil \& Environmental Engineering

2019

Preliminary Assessment of Ferrate Treatment of Metals in Acid

Mine Drainage

Joseph E. Goodwill

University of Rhode Island, goodwill@uri.edu

Julie LaBar

Debbie Slovikosky

William H.J. Strosnider

Follow this and additional works at: https://digitalcommons.uri.edu/cve_facpubs

The University of Rhode Island Faculty have made this article openly available.

Please let us know how Open Access to this research benefits you.

This is a pre-publication author manuscript of the final, published article.

Terms of Use

This article is made available under the terms and conditions applicable towards Open Access

Policy Articles, as set forth in our Terms of Use.

Citation/Publisher Attribution

Goodwill, J. E., J. LaBar, D. Slovikosky, and W. H. J. Strosnider. 2019. Preliminary Assessment of Ferrate

Treatment of Metals in Acid Mine Drainage. J. Environ. Qual., 48(5), 1549-1556. doi:10.2134/

jeq2019.02.0079

Available at: http://dx.doi.org/10.2134/jeq2019.02.0079

This Article is brought to you for free and open access by the Civil \& Environmental Engineering at DigitalCommons@URI. It has been accepted for inclusion in Civil \& Environmental Engineering Faculty Publications by an authorized administrator of DigitalCommons@URI. For more information, please contact digitalcommonsgroup@uri.edu. 


\section{Preliminary Assessment of Ferrate Treatment of Metals in Acid Mine Drainage}

3 Joseph E. Goodwill ${ }^{1}$

4 Julie LaBar ${ }^{2}$

5 Debbie Slovikosky ${ }^{3}$

6 William H. J. Strosnider ${ }^{4,5}$

81 Department of Civil and Environmental Engineering, University of Rhode Island, Kingston, RI

92 Science Department, Centenary University, Hackettstown, NJ

103 Environmental Engineering Program, Saint Francis University, Loretto, PA

114 Center for Watershed Research and Service, Saint Francis University, Loretto, PA

125 Baruch Marine Field Laboratory, University of South Carolina, Georgetown, SC

\section{ABBREVIATIONS}

15 AMD, acid mine drainage; DS, dissolved; LP, large particles; NP, nanoparticles; PZC, point of

16 zero charge; SP, small particles; UF, ultra-filtration; XPS, x-ray photoelectron spectroscopy

18 CORE IDEAS

19 - Ferrate likely a viable option for acid mine drainage treatment

20 - Oxidation of manganese with $\mathrm{NaOH}$ co-addition near stoichiometric requirement

21 - Resultant particles may challenge downstream clarification 


\section{ABSTRACT}

25 We report a preliminary assessment of ferrate $(\mathrm{Fe}(\mathrm{VI}))$ for the treatment of net-acidic mine

26 drainage (AMD), focused on precipitation of metals (i.e. iron and manganese) and subsequent

27 removal. Two dosing approaches were studied to simulate the two commercially viable forms of

28 ferrate production: $\mathrm{Fe}(\mathrm{VI})$ only, and $\mathrm{Fe}(\mathrm{VI})$ with sodium hydroxide $(\mathrm{NaOH})$. Subsequent metal

29 speciation was assessed via filter fractionation. When only $\mathrm{Fe}(\mathrm{VI})$ was added, the $\mathrm{pH}$ remained $<$

303.6 , and the precipitation of $\mathrm{Mn}$ and $\mathrm{Fe}$ was $<30 \%$ and $<70 \%$ at the highest, stoichiometrically

31 excessive, $\mathrm{Fe}(\mathrm{VI})$ dose. When $\mathrm{NaOH}$ and $\mathrm{Fe}(\mathrm{VI})$ were added simultaneously, precipitation of $\mathrm{Mn}$

32 was much more complete, at doses near the predicted oxidation stoichiometric requirement. The

33 optimal dosage of $\mathrm{Fe}(\mathrm{VI})$ for Mn treatment was $25 \mu \mathrm{M}$. The formation of $\mathrm{Mn}(\mathrm{VII})$ was noted at

$34 \mathrm{Fe}(\mathrm{VI})$ dosages above the stoichiometric requirement, which would be problematic in full-scale

35 AMD treatment systems. Precipitation of Fe was $>99 \%$ when only $\mathrm{NaOH}$ was added, indicating

36 oxidation by Fe(VI) did not play a significant role when added. Fe(III) and Al(III) particles were

37 relatively large, suggesting probable success in subsequent removal through sedimentation.

38 Resultant Mn-oxide particles were relatively small, indicating that additional particle

39 destabilization may be required to meet Mn effluent goals. Fe(VI) seems viable for the treatment

40 of AMD especially when sourced through on-site generation due to the coexistence of $\mathrm{NaOH}$ in

41 the product stream. More research in the use of $\mathrm{Fe}(\mathrm{VI})$ for AMD treatment is required to answer 42 extant questions.

\section{INTRODUCTION}

45 Abandoned mine drainage (AMD) is a global environmental issue (Wolkersdorfer et al., 2004a-

46 c; Sun et al., 2013; Strosnider et al., 2014). AMD commonly contains elevated metals 
47 (particularly Fe, Al, and Mn), acidity, and sulfate concentrations (Younger et al., 2002). There

48 are two common and effective approaches for AMD treatment: active and passive. Passive

49 treatment employs unrefined materials (e.g., limestone, compost) under gravity flow conditions

50 in engineered basins (e.g., ponds, limestone beds, wetlands, bioreactors). Active treatment

51 employs chemical dosing (e.g., $\mathrm{NaOH}, \mathrm{CaOH})$ and ongoing energy inputs (e.g., electricity for

52 aeration/mixing) in traditional wastewater treatment unit processes (e.g., clarifiers, aeration

53 basins). Hybrid systems also exist that combine passive and active approaches within the same

54 treatment train. Spontaneous removal of Fe and Al through oxidation (for Fe(II)) and

55 precipitation is a relatively straightforward process. However, rapid abiotic Mn removal requires

$56 \mathrm{pH}>9$, which is not achievable in passive treatment systems and relatively expensive in active

57 treatment systems (Younger et al., 2002; Skousen et al., 2017). Thus, the abiotic oxidation of

58 reduced $\mathrm{Mn}$ is a common concern in AMD treatment, both from passive and active perspectives.

60 Ferrate (Fe(VI)) is an oxidant of increasing focus in environmental research (Sharma et al.,

61 2016), that may have advantages in AMD. For example, $\mathrm{Fe}(\mathrm{VI})$ has a high oxidation potential at

62 low pH (Sharma et al., 2016), rapidly oxidizes of Mn (Goodwill et al., 2016), and leads to the in

63 situ formation of Fe oxides (Goodwill et al., 2015; Zheng and Deng, 2016) that may support

64 coagulation (Lv et al., 2018). Fe(VI) has also been shown to not directly produce halogenated

65 byproducts in common natural water matrices (DeLuca et al., 1983; Huang et al., 2016; Jiang et

66 al., 2016), although the formation of brominated byproducts has been noted (Huang et al., 2016;

67 Jiang et al., 2016). $\mathrm{Fe}(\mathrm{VI})$ exists as $\mathrm{FeO}_{4}^{-2}$ (aq), and has equilibria between several protonated

68 forms, as shown in Equations 1 through 3 (Carr, 2008; Rush et al., 1996; Sharma, 2002). 
$\mathrm{H}_{3} \mathrm{FeO}_{4}^{+} \leftrightarrow \mathrm{H}^{+}+\mathrm{H}_{2} \mathrm{FeO}_{4}, p K_{1}=1.6$

(Equation 1)

$71 \mathrm{H}_{2} \mathrm{FeO}_{4} \leftrightarrow \mathrm{H}^{+}+\mathrm{HFeO}_{4}^{-}, p K_{2}=3.5$

(Equation 2)

$72 \mathrm{HFeO}_{4}^{-} \leftrightarrow \mathrm{H}^{+}+\mathrm{FeO}_{4}^{-2}, p K_{3}=7.3$

(Equation 3)

$74 \mathrm{Fe}(\mathrm{VI})$ can be produced electrochemically utilizing an iron-based sacrificial anode in a strong

$75 \mathrm{NaOH}$ or $\mathrm{KOH}$ solution (Alsheyab et al., 2009; Dubrawski et al., 2018; Stanford et al., 2010).

$76 \mathrm{Fe}(\mathrm{VI})$ can also be made using a wet-oxidation approach, which includes oxidation of ferric iron

77 (commonly sourced as commercially available ferric sulfate or ferric chloride coagulants) by

78 sodium hypochlorite $(\mathrm{NaOCl})$ in a concentrated solution of $\mathrm{NaOH}$ (Ockerman and Schreyer,

79 1951). A version of the wet-oxidation method has been commercialized (Ciampi and Daly,

80 2009), with viable applications to industrial wastes. The Fe(VI) product resulting from either of

81 these production methods co-exists in a strongly alkaline solution, with positive and negative

82 implications of resulting $\mathrm{pH}$ changes of dosed waters depending on specific application and

83 water quality.

85 The $\mathrm{Fe}(\mathrm{VI})$ product resulting from either production method can be further refined, leading to a

86 high purity $(>95 \%)$ potassium ferrate $\left(\mathrm{K}_{2} \mathrm{FeO}_{4}\right)$ solid (Thompson et al., 1951). This additional

87 refinement step requires additional cost and complexity, but removes concerns of very alkaline

88 dosed solutions and the possibility of unreacted $\mathrm{NaOCl}$, and allows for off-site production and

89 shipment of a relatively stable, solid-phase product. Innovation has occurred with respect to

90 electrochemical production and subsequent refinement (Monzyk et al., 2013), with $\mathrm{K}_{2} \mathrm{FeO}_{4}$

91 product now commercially available.

92 
93 Unrefined $\mathrm{Fe}(\mathrm{VI})$ product (e.g. Fe(VI) in solution with high concentrations of $\mathrm{NaOH}$ ) may be

94 uniquely advantageous to the treatment of AMD, where increasing the $\mathrm{pH}$ is a primary concern.

$95 \mathrm{Fe}(\mathrm{VI})$ produced on-site may meet multiple treatment objectives in a single step including

96 increasing $\mathrm{pH}$, oxidizing reduced metals, and increasing aggregation of resultant metal-oxide

97 particles. This may lend an operational simplicity that AMD managers in more rural areas find

98 attractive. Alternatively, utilization of solid $\mathrm{K}_{2} \mathrm{FeO}_{4}$ product may be preferred in some situations,

99 due to the off-site production and corresponding lack of chemical inputs.

100

101 Despite these potential advantages there has not been a direct examination of Fe(VI) treatment of

102 AMD. Most prior work has focused on ferrate applications in drinking water (Goodwill et al.,

103 2016; Sharma, 2002; Song et al., 2016) and wastewater (Lee et al., 2009; Waite and Gray, 1984;

104 Yates et al., 2014). There have been several studies examining ferrate treatment of solid phase

105 mine tailings via heterogenous oxidation reactions (Murshed et al., 2003; Yu et al., 2013), in an

106 attempt to decrease subsequent acidic discharges (Singer and Stumm, 1970). Murshed et al.

107 (2003) found ferrate mitigates acid production by oxidizing sulfide to sulfates in heterogenous

108 reactions between ferrate and a mine tailings slurry. The oxidation of $\mathrm{H}_{2} \mathrm{~S}$ by ferrate in

109 homogenous aqueous phase reactions in laboratory and municipal wastewater matrices ( $\mathrm{pH}$

110 ranged 7 to 12) has also been demonstrated (Sharma et al., 1997). Yu et al. (2013) examined the

111 oxidation of several solid phase metal-sulfides at $\mathrm{pH} 9.0$ and also noted the generation of sulfate.

112 However, prior work on ferrate mitigation of mining wastes has focused on the oxidation of mine

113 tailings, and not the drainage that results from the tailings. Thus, it is uncertain how ferrate may

114 perform in the inherently complex matrix of AMD. Fe(VI) has been proposed as a solution to 
115 challenging Mn(II) removal from mine drainage (Neculita and Rosa, 2019), yet no published

116 data exist.

118 The overarching objective of this work was a preliminary examination of ferrate oxidation of

119 AMD, and a general assessment of the feasibility of ferrate oxidation for active or hybrid AMD

120 treatment systems. More specifically, the study focused on the stoichiometry, products and

121 qualitative kinetics of the reactions between $\mathrm{Fe}(\mathrm{VI})$ and several dissolved metals within an AMD

122 matrix. Special attention was paid to $\mathrm{Mn}$, as some abiotic passive systems have struggled to

123 decrease Mn concentrations to treatment goals (LaBar et al., 2011). A secondary objective was to

124 inform which $\mathrm{Fe}(\mathrm{VI})$ production method_-onsite production of $\mathrm{Fe}(\mathrm{VI})$ in a $\mathrm{NaOH}$ liquid stream,

125 or off-site production of $\mathrm{K}_{2} \mathrm{FeO}_{4}$ solid — may be most appropriate for AMD treatment.

\section{MATERIALS AND METHODS}

128 AMD studied in this work came from the Puritan discharge in Portage, Pennsylvania (PA) within

129 the Appalachian coal basin. The discharge is from an abandoned underground partially-flooded

130 and freely-draining coal mine. Water quality at the site has been monitored extensively over the

131 last decade. The mean $\mathrm{pH}$ of the discharge is 3.2, with no alkalinity, and average acidity of 134

$132 \mathrm{mg} / \mathrm{L}$ as $\mathrm{CaCO}_{3}$. Mean concentrations of Fe, $\mathrm{Al}$ and $\mathrm{Mn}$ are $9.4 \mathrm{mg} / \mathrm{L}, 11.2 \mathrm{mg} / \mathrm{L}$, and $1.9 \mathrm{mg} / \mathrm{L}$,

133 respectively. A simple Fe speciation model was developed in Geochemist Workbench (Bethke,

134 2008) for the Puritan AMD. Model results showed essentially all Fe was likely in the +3

135 oxidation state. 
137 Since 2012, the discharge has been partially treated using a baffled limestone bed. Treated

138 effluent has a mean $\mathrm{pH}$ of 7.1 and an alkalinity of $106 \mathrm{mg} / \mathrm{L}$; however, the system only removes

139 approximately $78 \%, 63 \%$, and $33 \%$ of the total Fe, Al, and $\mathrm{Mn}$, respectively. This particular

140 discharge qualifies for exemption from effluent discharge limits; however, typical limits from the

141 Pennsylvania Department of Environmental Protection include $3.0 \mathrm{mg} / \mathrm{L}$ and $2.0 \mathrm{mg} / \mathrm{L}$ for total

142 Fe and Mn, respectively. Similar requirements for Al do not exist. Organic carbon has not been 143 quantified, but is expected to be in trace amounts, as is typical of coal mine drainage in the 144 Appalachian Basin (Watzlaf et al., 2004).

146 Samples of AMD were collected directly at the outfall of the Puritan discharge, Collapsible

147 containers sealed with Parafilm were used to ensure no oxygen was entrained during sample 148 collection and transport. All experiments were executed within 48 hours of sample collection.

149 The turbidity and $\mathrm{pH}$ of collected samples was monitored to ensure no significant changes in 150 water quality between sampling and experimentation.

152 The oxidation experiments were executed by an adapted jar test procedure (Ma and Liu, 2002)

153 involving 1 L of AMD. The square reaction vessels (e.g. "jars”, B-Ker, Phipps \& Bird) had the 154 following dimensions: length $=4.5 \mathrm{in}$, width $=4.5 \mathrm{in}$, and height to water surface $=3$ in. Two 155 sets of experiments were done: one adding Fe(VI) only, and the other adding Fe(VI) with a 50\% $156 \mathrm{NaOH}$ solution, replicating the expected matrix of on-site generated solutions. $\mathrm{NaOH}$ solution

157 dose was set as the amount required to increase solution $\mathrm{pH}$ to approximately 5.25 , and 158 determined in preliminary titration experiments to be $6.8 \mathrm{~mL}$. Subsequently, $6.8 \mathrm{~mL}$ of $50 \%$ $159 \mathrm{NaOH}$ solution was added simultaneously with $\mathrm{Fe}(\mathrm{VI})$ in the set of experiments including $\mathrm{NaOH}$ 
160 co-addition. Fe(VI) was added by making a concentrated $(2 \mathrm{mM})$ solution from DI water and

$161 \mathrm{~K}_{2} \mathrm{FeO}_{4}($ Battelle Memorial Institute/Element 26) with an unbuffered $\mathrm{pH}$ of 9.2. The

162 concentration of $\mathrm{Fe}(\mathrm{VI})$ dosing solution was confirmed via direct spectrophotometric

163 measurement at $510 \mathrm{~nm}$ immediately prior to addition (Carr, 2006). Chemicals were dosed to the

164 reaction vessels under intense mixing $\left(\mathrm{G} \sim 350 \mathrm{sec}^{-1}\right)$. Mixing was then decreased $\left(\mathrm{G} \sim 75 \mathrm{sec}^{-1}\right)$

165 for a total time of 30 minutes, although reactions were observed to proceed more rapidly.

166 Duplicate experiments were conducted for each scenario, and preliminary metal concentrations

167 were initially measured using colorimetric methods (Eaton et al., 2005) adapted for use via

168 commerically available units (i.e. Hach reagents and spectrometer), in order to provide rapid

169 assessment, and adjustment of subsequent Fe(VI) dosages. The applicable colorimetric methods

170 for each metal are as follows: Hach FerroVer, \#8008 (Iron), Hach Low Range (LR) Mn Method,

171 \#8145 (Manganese) and Hach AluVer, \#8012 (Aluminum). Samples were collected from each

172 experimental condition, acidified to $1 \%$ nitric acid, and then final metal concentrations were

173 measured using an Inductively Coupled Plasma Atomic Emission Spectrometer (ICP-AES). ICP-

174 AES-generated concentrations were used for reporting. Means and standard deviations were

175 calculated, with reported error bars representing one standard deviation. ICP-AES analysis was

176 not available for an experimental control condition (with $50 \% \mathrm{NaOH}$ solution, and $\mathrm{Fe}(\mathrm{VI})=0$

$177 \mu \mathrm{M})$, and thus those data were generated only from colorimetric measurements.

179 Turbidity samples were drawn after 60 minutes of settling (e.g. no mixing) that succeeded the 30

180 minutes of slow mixing. Samples were drawn from a tap in the reactor vessel positioned

181 equidistant from the water surface elevation and the reactor bottom. Samples were drawn 
182 quiescently, to minimize perturbation of the particle suspension. Turbidity was measured with an

183 USEPA Method 180.1 compliant turbidimeter (HACH 2100).

185 The resulting metal (hydro)oxides were fractionated using a series of filters with progressively 186 smaller effective/pore sizes in a method previously developed for determining the size and 187 oxidation state of Mn particles (Carlson et al., 1997). The filters included a fine glass fiber $188(\mathrm{GF} / \mathrm{F})($ effective size $=0.7 \mu \mathrm{m})$, a microfiltration $(\mathrm{MF})$ membrane (pore size $=0.2 \mu \mathrm{m})$, and an 189 ultrafiltration (UF) membrane (molecular weight cut-off $=30 \mathrm{KDa}$ ). Particles retained on the $190 \mathrm{GF} / \mathrm{F}$ were defined as large particles (LP). Particles passing the GF/F but retained on the MF 191 were called small particles (SP). Particles passing the MF but retained on the UF were called 192 nanoparticles (NP). Any material passing the $30 \mathrm{KDa}$ UF was operationally defined as dissolved 193 (DS) (Tobiason et al., 2008).

\section{RESULTS AND DISCUSSION}

\section{Impact on pH and Dissolved Metals}

197 Figure 1 includes the resulting $\mathrm{pH}$ and dissolved metal concentrations following the two Fe(VI)

198 dosing regimes as a function of $\mathrm{Fe}(\mathrm{VI})$ dose. $\mathrm{pH}$ did not increase appreciably in the no $\mathrm{NaOH}$ 199 condition when dosed $\mathrm{Fe}(\mathrm{VI})$ was $100 \mu \mathrm{M}$ or less. Even at the highest $\mathrm{Fe}(\mathrm{VI})$ dose, there was 200 only a small increase in $\mathrm{pH}$ from 3.2 to 3.6. The $\mathrm{pH}$ in the condition with $\mathrm{NaOH}$ ranged from 2015.25 to 6.8 , at the lowest and highest Fe(VI) dosages, respectively.

203 The (lack of) impact on $\mathrm{pH}$ by $\mathrm{Fe}(\mathrm{VI})$ in the no $\mathrm{NaOH}$ condition can be explained by considering 204 the acidity of the AMD and alkalinity of $\mathrm{Fe}(\mathrm{VI}) . \mathrm{Fe}(\mathrm{VI})$ primarily exists as $\mathrm{FeO}_{4}{ }^{-2}$ in an aqueous 
205 solution at pH 9.2 used for dosing (see Equation 3), and can be considered the conjugate base of 206 the other protonated forms (Equations 1 and 2). As such, the alkalinity of an $\mathrm{FeO}_{4}{ }^{-2}$ dose can be 207 calculated with respect to calcium carbonate $\left(\mathrm{CaCO}_{3}\right)$, based on their equivalent weights (Eaton 208 et al., 2005). In this way, a $300 \mu \mathrm{M} \mathrm{FeO}_{4}{ }^{-2}$ dose yields approximately $30 \mathrm{mg} / \mathrm{L}$ alkalinity as

$209 \mathrm{CaCO}_{3}$. The final mixed $\mathrm{pH}$ can be estimated at 3.8 based on the of the acidity of the AMD and 210 alkalinity equivalent of $300 \mu \mathrm{M} \mathrm{FeO}_{4}{ }^{-2}$ dose, assuming a system open to the atmosphere (Stumm 211 and Morgan, 2012), which is in general agreement with measurements. Clearly, it would take 212 considerably more $\mathrm{FeO}_{4}^{-2}$ to raise the $\mathrm{pH}$ of the AMD near a typical treatment goal of $>6.0$ 213 (Johnson and Hallberg, 2005). Thus, results support the conclusion that $\mathrm{FeO}_{4}{ }^{-2}$ alone is likely 214 inadequate as a single treatment approach to AMDs of similar or greater acidity. A combination 215 of $\mathrm{NaOH}$ and $\mathrm{Fe}(\mathrm{VI})$ was adequate to increase the resulting $\mathrm{pH}$ to circumneutral values. Results 216 indicate that the combination of $\mathrm{Fe}(\mathrm{VI})$ in a high strength $\mathrm{NaOH}$ solution - similar to that 217 generated from on-site electrochemical of wet-oxidation methods - may yield significantly less 218 acidic $\mathrm{pH}$ values. Methods for producing $\mathrm{Fe}(\mathrm{VI})$ in a $\mathrm{KOH}$ solution also exist, and it is 219 anticipated that impact on $\mathrm{pH}$ would be the same to that of $\mathrm{NaOH}$, assuming similar molar 220 dosages. 


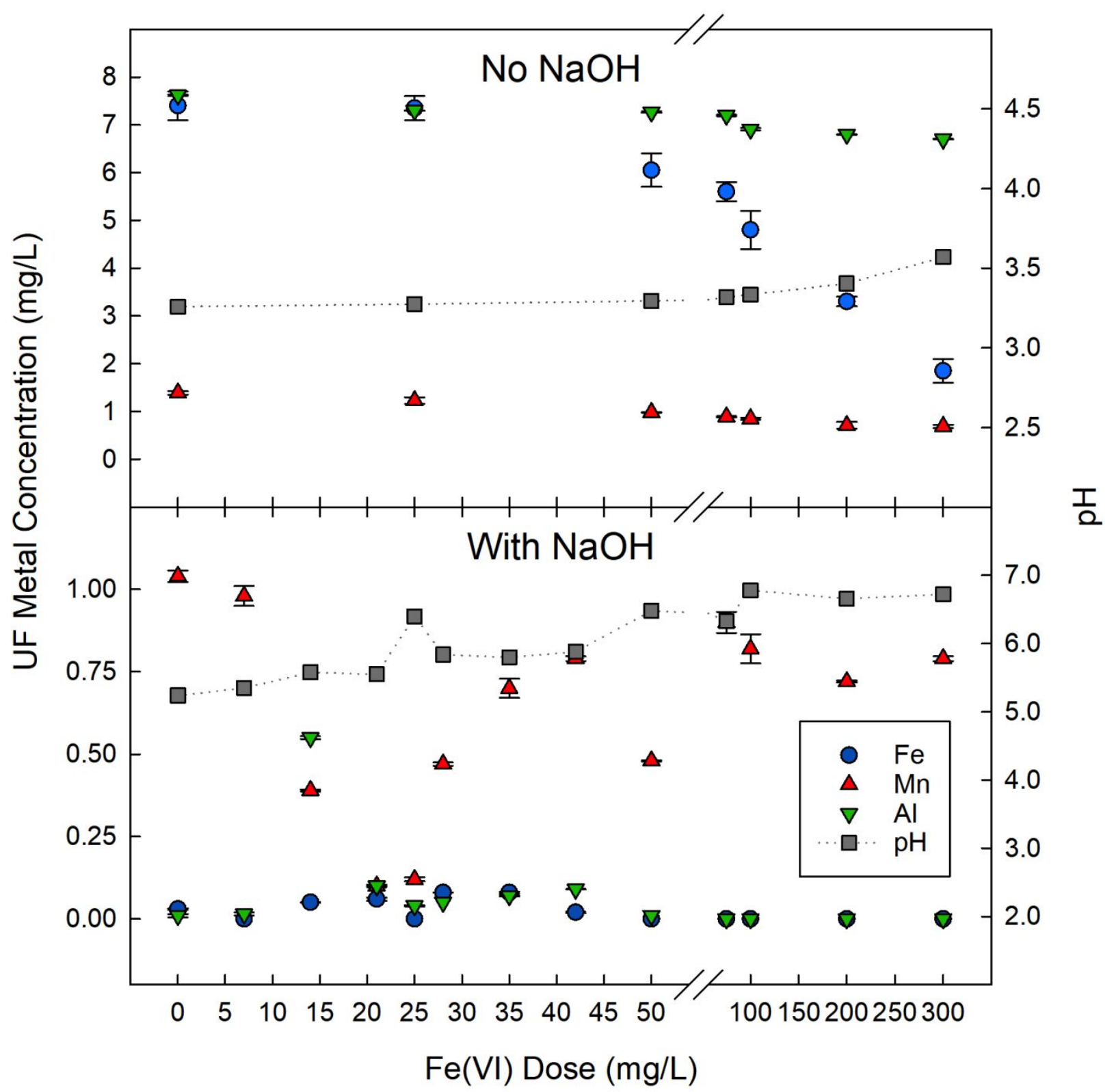

Fig 1. Metal concentrations after $30 \mathrm{kDa}$ membrane ultrafiltration (UF) and $\mathrm{pH}$ following ferrate

224 oxidation of acid mine drainage with and without $\mathrm{NaOH}$ co-addition.

226 Figure 1 also includes operationally-defined dissolved metal concentrations following Fe(VI)

227 addition with and without co-addition of $\mathrm{NaOH}$. The extent of metals precipitation clearly 
228 depended on the co-addition of $\mathrm{NaOH}$. When $\mathrm{NaOH}$ was not added and the $\mathrm{pH}$ was relatively

229 low, precipitation of $\mathrm{Fe}, \mathrm{Mn}$, and $\mathrm{Al}$ was incomplete. $74 \%, 29 \%$, and $21 \%$ of the $\mathrm{Fe}, \mathrm{Mn}$ and $\mathrm{Al}$

230 were separated by the UF membrane, respectively, at the highest Fe(VI) dose of $300 \mu \mathrm{M}$.

232 Precipitation of metals was more complete with $\mathrm{NaOH}$ and $\mathrm{Fe}(\mathrm{VI})$ co-addition. In a control

233 condition, where only $\mathrm{NaOH}$ was added (e.g. $\mathrm{Fe}(\mathrm{VI})$ dose $=0 \mathrm{mg} / \mathrm{L}$ ), almost all $\mathrm{Fe}$ and $\mathrm{Al}$ did

234 not pass the UF membrane. This indicates that Fe(VI) oxidation did not play a significant role in

235 changing the oxidation and/or particulate state of Fe or Al in the AMD. However, the majority of

236 Mn still passed the UF membrane, until Fe(VI) was included with the $\mathrm{NaOH}$.

238 The concentration of all metals reached a minimum at a Fe(VI) dose of $25 \mu \mathrm{M}$, which includes a 239 decrease in operationally-defined dissolved Fe, Mn and Al concentration by 98\%, 93\% and 97\%, 240 respectively. $\mathrm{Fe}(\mathrm{VI})$ dosages greater than $25 \mu \mathrm{M}$ did not further decrease metal concentrations 241 despite additional increases in $\mathrm{pH}$, therefore $25 \mu \mathrm{M}$ represents the optimal dosage in this case.

242 However, dissolved Mn concentrations did increase at Fe(VI) dosages above $25 \mu \mathrm{M}$. A persistent

243 pink color was observed in these situations, which was confirmed to be Mn(VII) via an

244 assessment of visible light absorbance, featuring two distinct peaks at 526 and 546 nm (data not

245 shown) (Den Boef et al., 1958). The in-situ formation of Mn(VII) from the oxidation of Mn(II)

246 by $\mathrm{Fe}(\mathrm{VI})$ has been previously noted in a laboratory drinking water matrix (Goodwill et al.,

247 2016). Results here demonstrate the potential for this to occur in an AMD water matrix under

248 simultaneous addition of $\mathrm{Fe}(\mathrm{VI})$ and $\mathrm{NaOH}$. The in-situ formation of $\mathrm{Mn}(\mathrm{VII})$ during AMD

249 treatment could present ecological and aesthetic concerns to receiving water bodies. Attention

250 should be paid to the potential for optimal Fe(VI) based on theoretical stoichiometry. 


\section{Metal Oxidation Stoichiometry}

253 Figure 2 includes the results from experiments up to the previously described optimal Fe(VI) 254 dose of $25 \mu \mathrm{M}$, in terms Fe and Mn precipitated on a molar basis. Figure 2 also includes the 255 theoretical stoichiometry of the oxidation reaction between $\mathrm{Fe}(\mathrm{II})$ and Fe(VI) (Lee et al., 2014), 256 and $\mathrm{Mn}(\mathrm{II})$ and $\mathrm{Fe}(\mathrm{VI})$ (Goodwill et al., 2016), respectively. Lee et al. (2014) demonstrated a 3:1 257 stoichiometry in an $\mathrm{N}_{2}$ purged, circumneutral $\mathrm{pH}$ solution with $5 \mathrm{mM}$ carbonate buffer (see 258 Figure SI-14 in that work), summarized as Equation 4. Goodwill et al. (2016) demonstrated a 2:3 259 stoichiometry at pH 6.2 and 7.5 in a $1 \mathrm{mM}$ carbonate buffered water, summarized as Equation 5, 260 with final oxidation states confirmed via x-ray photoelectron spectroscopy (XPS). In that work, 261 Mn was sourced as a manganous salt, and known to be in the +2 (e.g. reduced) oxidization state. 262 Both equations are net, and do not show potential intermediate steps including $\mathrm{Fe}(\mathrm{V})$ or $\mathrm{Fe}(\mathrm{IV})$.

$2643 F e(I I)+F e(V I) \rightarrow 4 F e(I I I)$

265 266

267 268 269
$3 M n(I I)+2 F e(V I) \rightarrow 3 M n(I V)+2 F e(I I I)$

(Equation 4)

(Equation 5)

In Figure 2, data points falling to the right of the theoretical stoichiometric ratio represent dosages of $\mathrm{Fe}(\mathrm{VI})$ that caused precipitation less than the expected oxidation of $\mathrm{Fe}(\mathrm{II})$ or $\mathrm{Mn}(\mathrm{II})$. Similarly, points to the left represent precipitation beyond reduced metal oxidation expectations for the respective $\mathrm{Fe}(\mathrm{VI})$ dose. Both $\mathrm{Fe}$ and $\mathrm{Mn}$ precipitation were well below stoichiometric expectations when no $\mathrm{NaOH}$ was added. This suggests Fe(VI) auto-decay (e.g. oxidation of water) competes with other redox pathways, or that the Fe and Mn were already in an oxidized state prior to $\mathrm{Fe}(\mathrm{VI})$ addition. The apparent rate constant $\left(\mathrm{k}_{\mathrm{app}}\right)$ of $\mathrm{Fe}(\mathrm{VI})$ auto-decay has been 
274 quantified by Lee et al. (2014), and ranges from $\sim 5 \times 10^{4} \mathrm{M}^{-1} \mathrm{~s}^{-1}$ at $\mathrm{pH} 3.0$ to $\sim 1 \times 10^{4} \mathrm{M}^{-1} \mathrm{~s}^{-1}$ at

$275 \mathrm{pH}$ 3.5. However, Lee at al. utilized phosphate buffers to sequester Fe(III) iron particles, which

276 retards the rate of $\mathrm{Fe}(\mathrm{VI})$ decay (Jiang et al., 2015). Thus, the actual Fe(VI) auto-decay in an

277 AMD matrix may be greater. Lee et al. (2014) estimated a second-order rate constant $\left(\mathrm{k}_{2}\right)$ of $>>$

$2785 \times 10^{6} \mathrm{M}^{-1} \mathrm{~s}^{-1}$ for $\mathrm{Fe}(\mathrm{II})$ oxidation by $\mathrm{Fe}(\mathrm{VI})$ at $\mathrm{pH}$ 5.0.

279

280 Similarly, Goodwill et al. (2016) estimated a $\mathrm{k}_{2}$ for $\mathrm{Mn}(\mathrm{II})$ oxidation by $\mathrm{Fe}(\mathrm{VI})$ of $>5 \times 10^{4} \mathrm{M}^{-1} \mathrm{~s}^{-}$

$281{ }^{1}$ when $\mathrm{pH}<8.0$ in carbonate buffered water. This prior work suggests oxidation of Fe(II) and

$282 \mathrm{Mn}(\mathrm{II})$ by $\mathrm{Fe}(\mathrm{VI})$ in acid environments proceeds as fast or faster than $\mathrm{Fe}(\mathrm{VI})$ auto-decay in a

283 phosphate buffered laboratory water matrix. Alternative kinetic explanation may be found in the

284 potential speciation differences in the metal hydroxides as a function of $\mathrm{pH}$ not included in the

285 prior estimations. For example, the estimate of $\mathrm{k}_{2}$ by Goodwill et al. does not account for

286 speciation differences between $\mathrm{Mn}^{+2}$, and $\mathrm{Mn}(\mathrm{OH})^{+1}$ (aq) as a function of $\mathrm{pH}$. In general, the

287 kinetics of Mn oxidation with various oxidants decreases as $\mathrm{pH}$ decrease due to increased

288 fractions of $\mathrm{Mn}^{+2}$ versus $\mathrm{Mn}(\mathrm{OH})^{+1}(\mathrm{pK}=10.6)$ (Allard et al., 2013; Knocke et al., 1987;

289 Morgan and Stumm, 1964). It is also possible that Fe and Mn formed very small $(<20 \mathrm{~nm})$

290 particles that were operationally defined as dissolved. The oxidation-reduction pathways of

$291 \mathrm{Fe}(\mathrm{VI})$ in the presence of acid are complex and an active area of research, including the

292 "activation" of ferrate by accelerating decay to oxidize recalcitrant organics by increasing

293 formation of reactive iron-species (Feng et al., 2018). 


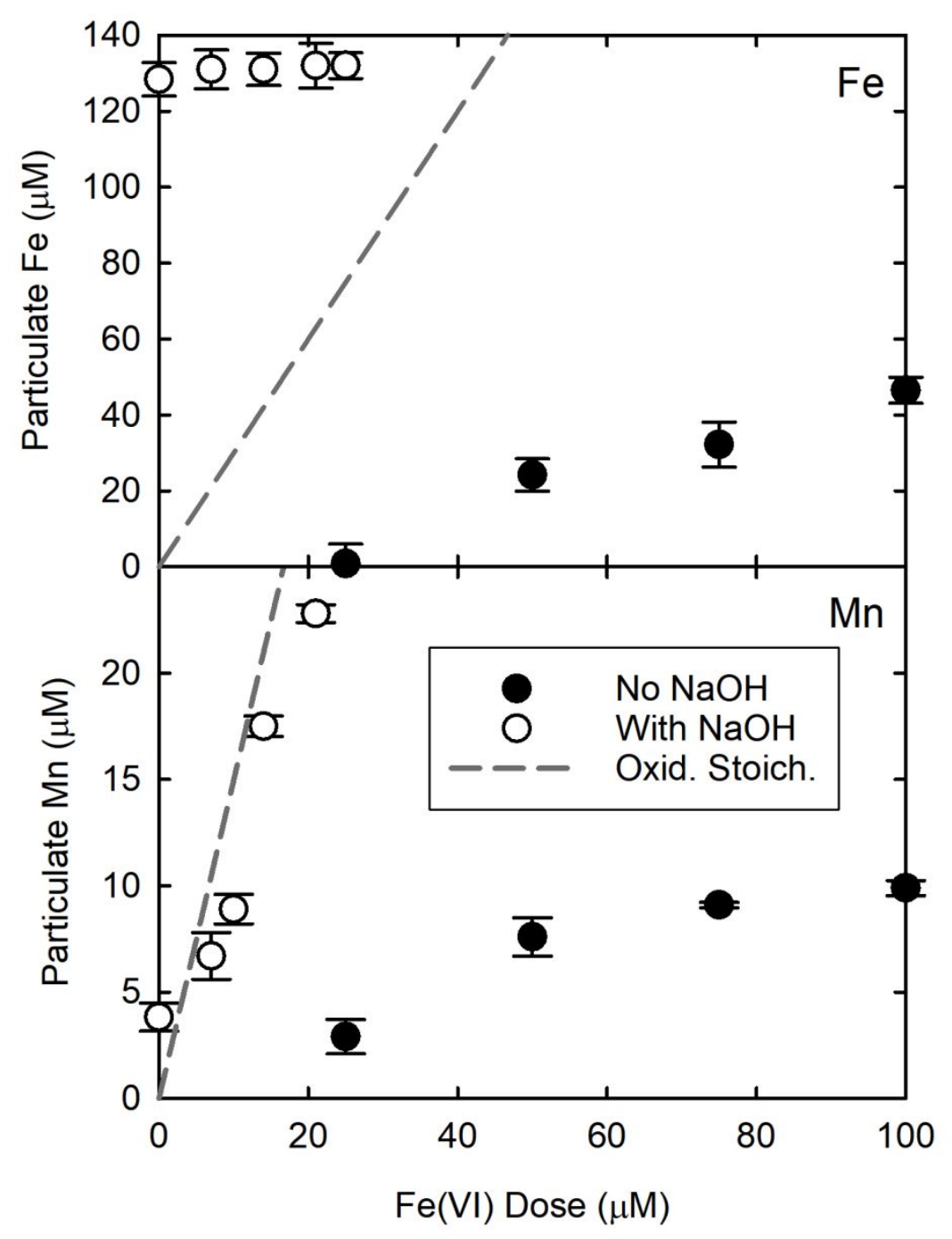

296 Fig 2. Molar concentrations of precipitated Fe and Mn for a given Fe(VI) dose in both with and 297 without $6.8 \mathrm{~mL}$ of $50 \% \mathrm{NaOH}$ solution conditions. Expected Fe oxidation stoichiometry of 298 3Fe(II):Fe(VI) from Lee et al., 2014. Expected Mn oxidation stoichiometry of 3Mn(II):2Fe(VI) 299 from Goodwill et al., 2016.

301 Fe and Mn may exist in numerous species, depending on $\mathrm{pH}$, concentration (i.e. relative 302 saturation) and oxidization-reduction potential (ORP) of solution. For example, in acidic 303 environments, Fe may exist as $\mathrm{Fe}(\mathrm{III})$ and remain in a dissolved form, such as $\mathrm{Fe}^{+3}{ }_{(\mathrm{aq})}$ or 
$304 \mathrm{Fe}(\mathrm{OH})^{+2}{ }_{(\mathrm{aq})}$. In the $\mathrm{pH}$ range $3-4$ even minor changes in $\mathrm{pH}$ and/or ORP will impact this

305 speciation. If soluble forms of $\mathrm{Fe}(\mathrm{III})$ or $\mathrm{Mn}(\mathrm{III} / \mathrm{IV})$ resulted from AMD oxidation by ferrate

306 without $\mathrm{NaOH}$ co-addition, then they would have been operationally defined as dissolved, and

307 thus fall to the right of the theoretical stoichiometry in Figure 2. Results from Fe speciation

308 modeling show the overwhelming majority of Fe was already as Fe(III). Deeper exploration of

309 AMD metal speciation following $\mathrm{Fe}(\mathrm{VI})$ addition without additional $\mathrm{pH}$ control is required to

310 more fully understand this system; however, it seems unlikely that this treatment regime would

311 warrant serious consideration for full-scale adaptation.

312

313 Much more precipitation of Fe and Mn occurred as a function of $\mathrm{Fe}(\mathrm{VI})$ dose when $\mathrm{NaOH}$ was

314 added simultaneously. For Fe, precipitation far exceeded the assumed oxidization reaction

315 stoichiometry between $\mathrm{Fe}(\mathrm{II})$ and $\mathrm{Fe}(\mathrm{VI})$ as shown in Equation 5. This includes the control

316 situation where only $\mathrm{NaOH}$ was added, and the $\mathrm{Fe}(\mathrm{VI})$ dose was zero- essentially all Fe was

317 defined as particulate. Coupled with the model prediction of primarily Fe(III) existing in the

318 untreated AMD, this result supports the conclusion that $\mathrm{Fe}(\mathrm{VI})$ played an insignificant role, and

319 changes in $\mathrm{pH}$ from $\mathrm{NaOH}$ addition decreased the solubility of $\mathrm{Fe}(\mathrm{III})$, without changes in

320 oxidation state. Alternatively, an electrophile other than those attributed to Fe(VI) participated in

321 a redox reaction with $\mathrm{Fe}$ when the $\mathrm{pH} \geq 5.5$ (see Figure 1 for resulting $\mathrm{pH}$ values for all

322 experiments). It is likely that dissolved oxygen $\left(\mathrm{O}_{2(\mathrm{aq})}\right)$ was present during the reaction, as the

323 reaction was open to the atmosphere under a turbulent mixing regime. Also, self-decay of

$324 \mathrm{Fe}(\mathrm{VI})$, leads to the in-situ production of $\mathrm{O}_{2}$, with molar yields of approximately $60 \%$ (Lee et al.,

325 2014). Additional oxidation experiments in controlled anoxic conditions would be required to 
326 fully confirm this; however, it is anticipated that full-scale AMD treatment with Fe(VI) would

327 also be open to the atmosphere.

329 Precipitation of $\mathrm{Mn}$ was also more complete with $\mathrm{NaOH}$ and $\mathrm{Fe}(\mathrm{VI})$ co-addition, and approached

330 the expected theoretical stoichiometry as shown in Equation 6. Also, results from the $\mathrm{NaOH}$-only

331 control showed a small amount $(\sim 20 \%)$ of Mn was defined as particulate. There are several

332 important implications of this result. First, this supports the conclusion that Fe(VI) oxidized

333 dissolved $\mathrm{Mn}(\mathrm{II})$, and $\mathrm{Mn}(\mathrm{IV})$ and $\mathrm{Fe}(\mathrm{III})$ were the final products from the reaction (see Equation

334 5), as the existence and/or formation of other Mn oxidation states would have led to a different

335 stoichiometric relationship, and a divergence from the theoretical line included in Figure 2. The

336 oxidation kinetics of $\mathrm{Mn}(\mathrm{II})$ and $\mathrm{O}_{2}$ are very slow $\left(\mathrm{k}_{2} \sim 10^{-9}\right.$, at $\mathrm{pH}=6.0$ ) (Pankhow and Morgan,

337 1981). Secondly, it seems almost all Fe(VI) reacted with $\mathrm{Mn}(\mathrm{II})$ and did not proceed via other

338 oxidation-reduction pathways or Fe(VI) self-decay. Comparative kinetics supports this

339 conclusion, based on the previously discussed respective estimated $\mathrm{k}_{2}$ values for $\mathrm{Fe}(\mathrm{VI})$

340 oxidation of $\mathrm{Mn}(\mathrm{II})$ and $\mathrm{Fe}(\mathrm{VI})$ auto-decay at near-neutral $\mathrm{pH}$ values. More study is required to

341 fully elucidate the redox reactions between $\mathrm{Mn}(\mathrm{II})$ and $\mathrm{Fe}(\mathrm{VI})$ in the relatively complex AMD

342 matrix; however, results in Figure 2 indicate Fe(VI) addition to AMD may support Mn treatment

343 goals at dosages near the theoretical stoichiometric requirement. This selectivity has also been

344 noted with respect to organic carbon in prior studies. The presence of organic carbon at levels

345 much higher than what is typical in Appalachian coal mine AMD did not significantly increase

346 the amount of $\mathrm{Fe}(\mathrm{VI})$ required for complete $\mathrm{Mn}(\mathrm{II})$ oxidation (Goodwill et al., 2016). 
348 Adsorption of aqueous phase metals onto metal oxide surfaces may have taken place at the

349 experimental conditions in our study. The methods utilized do not enable the differentiation

350 between adsorbed species and the particle metal, which require surface techniques such as XPS

351 (Cerrato et al., 2011), or similar. Adsorbed aqueous metals would have been operationally

352 defined as either LP, SP or NP, (depending on the size of the adsorbent particle) and served to

353 shift points in Figure 2 vertically. Figure 2 supports limited adsorption of Mn(II) based on results

354 being proximate to expected stoichiometry. Adsorption of $\mathrm{Mn}$ (II) onto metal oxides is

355 proportional to $\mathrm{pH}$, with limited adsorption expected when $\mathrm{pH}<6.0$ (Morgan and Stumm, 1964),

356 as was the case in most all of the Fe(VI) dosages reported in Figure 2.

\section{Size Fractionation of Resulting Particles}

359 Figure 3 includes the metal fractionation results for selected Fe(VI) dosages, with and without

$360 \mathrm{NaOH}$. Most metals remained defined as dissolved following even the highest dose of Fe(VI)

361 without $\mathrm{NaOH}$ co-addition. Again, results of the Fe speciation model indicate the most Fe was in

362 the +3 oxidation state, even though it was found to pass the filtration steps in this study. Only

$36330 \%$ of total $\mathrm{Mn}$ and $65 \%$ of total Fe was in a particulate phase after a $\mathrm{Fe}(\mathrm{VI})$ dose of $100 \mu \mathrm{M}$

364 (without $\mathrm{NaOH}$ ); however, almost all the particles that did form were operationally defined as

365 LP, indicating aggregation resulting from the low solution $\mathrm{pH}$. Ferrate resultant Fe(III) particles

366 have been found to have a point of zero charge (PZC) at $\mathrm{pH} 3.0$ to 3.6 in natural water matrices

367 with low dissolved organic carbon (Goodwill et al., 2015; Lv et al., 2018), suggesting optimal

368 aggregation in that $\mathrm{pH}$ range. However, particle surface chemistry in the oxidized AMD matrix is

369 expected to be complex due to the potential hydrolysis of $\mathrm{Al}$ and $\mathrm{Fe}$ (e.g. dual coagulation)

370 (Johnson and Amirtharajah, 1983) leading to the formation of polymeric hydrolysis products 
371 (Duan and Gregory, 2003). The effect of mixing conditions on aluminum precipitation is also

372 important (Clark et al., 1993), but not examined in the context of this preliminary study. More

373 work on this topic is a focus of future research towards coagulation process optimization in an

374 AMD treatment context.

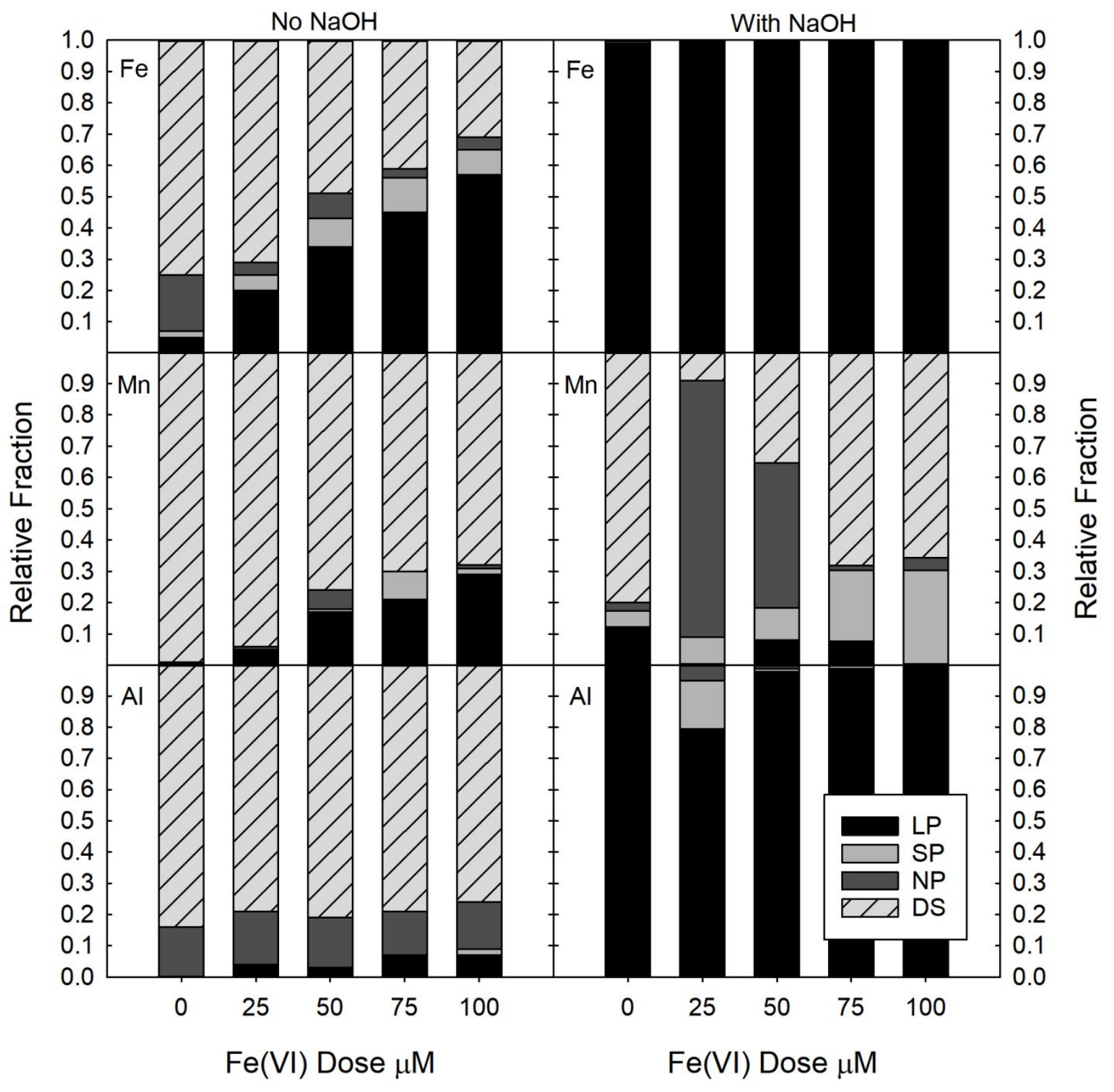


377 Fig. 3. Size fractionation of metal particles resulting from the oxidation of acid mine drainage by

378 ferrate, on a mass of metal basis, with and without the co-addition of $6.8 \mathrm{~mL}$ of $50 \% \mathrm{NaOH}$

379 solution. (LP = Large Particles, $\mathrm{SP}=$ Small Particles, NP = Nanoparticles, $\mathrm{DS}=$ Dissolved).

381 Particle size distributions with $\mathrm{NaOH}$ differed with almost all $\mathrm{Fe}$ and $\mathrm{Al}$ in a particulate form in 382 the only $\mathrm{NaOH}$ condition. However, most $\mathrm{Mn}$ remained dissolved until including a Fe(VI) dose 383 of $25 \mu \mathrm{M}$. Therefore, the precipitation of Fe may be attributable to the increase in $\mathrm{pH}$ from $384 \mathrm{NaOH}$ alone, as supported by results in Figure 2. 83\% of Mn resulting from oxidation was 385 characterized as NP. Prior investigations have noted the formation of nanoscale (e.g. colloidal) 386 Mn particles following exposure of Mn(II) to strong oxidants (Knocke et al., 1991; Reckhow et 387 al., 1991; Tobiason et al., 2016). The PZC of Mn-oxide particles in a laboratory water matrix 388 was found to occur below pH 3 (Morgan and Stumm, 1964), indicating the possibility of a stable 389 Mn colloidal suspension in the $\mathrm{pH}$ ranges in this study with $\mathrm{NaOH}$ co-addition. The Mn particles 390 formed without $\mathrm{NaOH}$ co-addition were significantly larger. Removing Mn NPs from solution 391 may be challenging (Brandhuber et al., 2013; Islam et al., 2010), however, it may be possible to 392 optimize particle aggregation by decreasing the amount of $\mathrm{NaOH}$.

394 Approximately $75 \%$ and $98 \%$ of $\mathrm{Al}$ and $\mathrm{Fe}$, respectively, were defined as LP following a ferrate 395 dose of $25 \mu \mathrm{M}$ with $\mathrm{NaOH}$ co-addition. At higher ferrate dosages nearly all $\mathrm{Al}$ and Fe was LP, 396 on a mass basis. In these situations, the resulting $\mathrm{pH}$ ranged from 6.0 to 6.6 (see Figure 1), which 397 is much higher than the PZCs for Al and Fe (hydr)oxides (Duan and Gregory, 2003; Faust and 398 Aly, 1998; Stumm and O’Melia, 1968; Van Benschoten and Edzwald, 1990). Aggregation in this $399 \mathrm{pH}$ range may be suboptimal due to charge reversal and repulsive forces; however, the 
400 opportunity for sweep flocculation exists due to the elevated range of total metal in the oxidized

401 AMD, especially at the higher dosages of Fe(VI) (Davis and Edwards, 2014; Dentel, 1991). In

402 this regime, enmeshment in metal precipitates with sufficient kinetic energy may overcome

403 repulsive forces, leading to improved aggregation in a single or dual coagulation situation

404 (Dentel, 1991; Graham et al., 2010; Johnson and Amirtharajah, 1983).

405

406 Settling of Resultant Particles

407

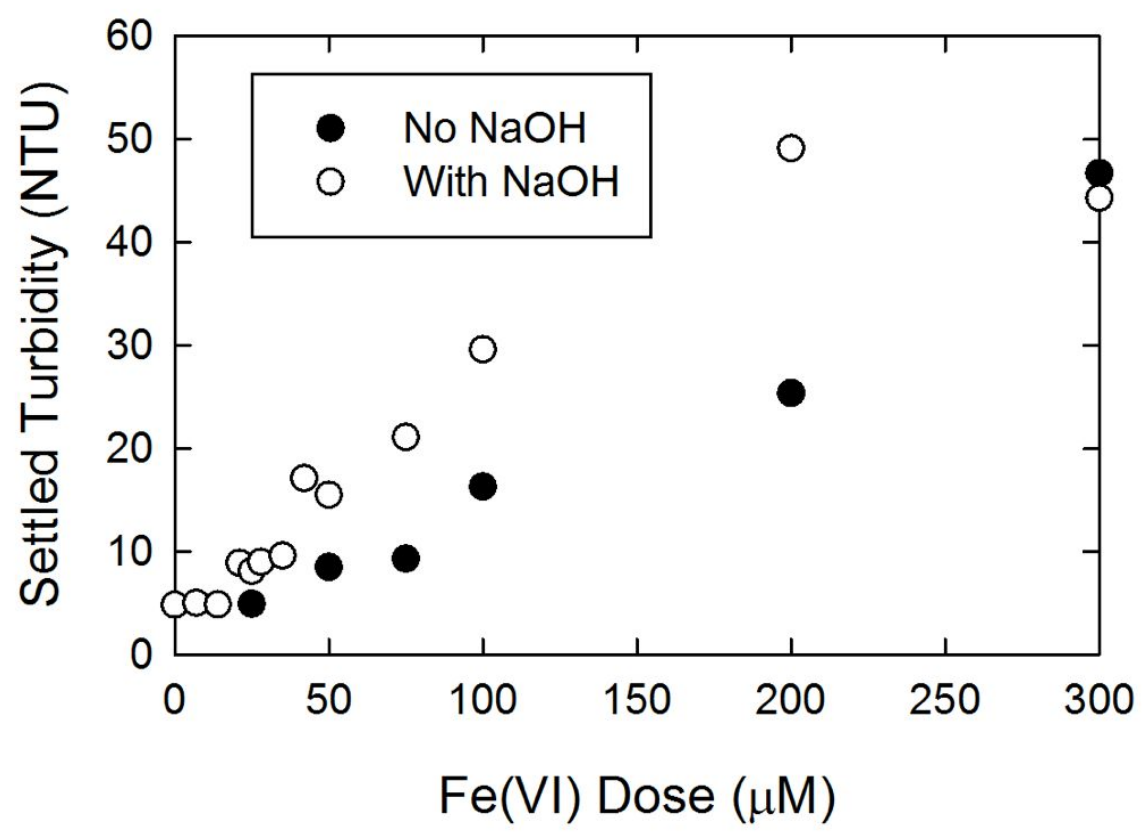

409 Fig 4. Turbidity of AMD solutions following various ferrate dosages, with and without the co-

410 addition of $6.8 \mathrm{~mL}$ of $50 \% \mathrm{NaOH}$ solution.

411

412 Figure 4 includes results for settled turbidity after Fe(VI) addition with and without $\mathrm{NaOH}$ co-

413 addition. Turbidity was elevated following treatment in both conditions, and directly

414 proportional to $\mathrm{Fe}(\mathrm{VI})$ dose. Turbidity was higher in most Fe(VI) dosages with the co-addition of 
$415 \mathrm{NaOH}$, likely due to lower solubility of $\mathrm{Al}$ and Fe and more complete oxidation of Mn (Sanchez

416 2007). Settling in both conditions was poor as determined by high residual turbidity. The poor

417 settling of ferrate resultant particles has been noted previously in an advanced wastewater

418 treatment context (Zheng and Deng, 2016).

420 The poor settling of other metal oxide particles may be attributable to the small extent of particle 421 destabilization. Surface charge of resultant particle suspensions was not able to be quantified, as 422 would likely be the case in isolated pseudo-passive systems. Attempts at optimization of dosing 423 on settled water turbidity may be helpful. Both topics should be the focus of future research. A

424 high turbidity discharge could create ecological and/or regulatory issues, especially in receiving 425 waters with sensitive aquatic life. Subsequent passive (e.g., sedimentation ponds, wetlands) or 426 active (e.g., clarifiers) may not be adequate for particle separation without enhanced coagulation 427 and/or flocculation.

429 ACKNOWLEDGEMENTS

430 This is contribution number 1870 for the Belle W. Baruch Institute for Marine and Costal 431 Sciences.

\section{CONCLUSIONS}

$434 \mathrm{Fe}(\mathrm{VI})$ is an interesting alternative treatment for AMD, and seems especially effective at 435 oxidizing dissolved Mn within an AMD matrix, at dosages near the minimum stoichiometric 436 requirement when $\mathrm{pH}>5.0$. The co-addition of $\mathrm{Fe}(\mathrm{VI})$ and $\mathrm{NaOH}$ seems to yield high 437 performance and operational simplicity, and currently available commercial options for this 
438 exist. The addition of $\mathrm{Fe}(\mathrm{VI})$ without $\mathrm{NaOH}$ proved inadequate and full-scale adaption of this

439 approach seems unlikely. Further research is required to assess impacts on trace metals and the 440 stability of the particle suspension resulting from Fe(VI) oxidation, appropriate clarification 441 process steps, and to confirm the final speciation of metal oxides produced. Also, the dose of

$442 \mathrm{NaOH}$ may be adjusted to optimize $\mathrm{Fe}(\mathrm{VI})$ oxidation effectiveness while minimizing negative 443 surface charges.

\section{REFERENCES}

446 Allard, S., Fouche, L., Dick, J., Heitz, A., Von Gunten, U., 2013. Oxidation of manganese(II)

447 during chlorination: Role of bromide. Environ. Sci. Technol. 47, 8716-8723.

448 doi:10.1021/es401304r

449 Alsheyab, M., Jiang, J.Q., Stanford, C., 2009. On-line production of ferrate with an

450 electrochemical method and its potential application for wastewater treatment--a review. J.

451 Environ. Manage. 90, 1350-6. doi:10.1016/j.jenvman.2008.10.001

452 Bethke, C., 2008. Geochemical and Biogeochemical Reaction Modeling, $2^{\text {nd }}$ ed. Cambridge $453 \quad$ University Press.

454 Brandhuber, P., Clark, S., Knocke, W., Tobiason, J., 2013. Guidance for the Treatment of 455 Manganese. Water Research Foundation, Denver, CO.

456 Carlson, K.H., Knocke, W.R., Gertig, K.R., 1997. Optimizing treatment through Fe and Mn 457 fractionation. J. / Am. Water Work. Assoc. 89, 162-171.

458 Carr, J., 2008. Kinetics and product identification of oxidation by ferrate (VI) of water and 459 aqueous nitrogen containing solutes, in: Sharma, V. (Ed.), ACS Symp. Ser. American 460 Chemical Society, Washington, pp. 189-196. 
461

462

463

464

465

466

467

468

469

470

471

472

473

474

475

476

477

478

479

480

481

482

483

Carr, J.D., 2006. Kinetics and product identification of oxidation by ferrate(VI) of water and aqueous nitrogen containing solutes. Abstr. Pap. Am. Chem. Soc. 232, 495.

Ciampi, L.E., Daly, L.J., 2009. Methods of synthesizing a ferrate oxidant and its use in ballast water. US7476342B2.

Clark, M.M., Srivastava, R.M., David, R., 1993. Mixing and Aluminum Precipitation. Environ. Sci. Technol. 27, 2181-2189. doi:10.1021/es00047a027

Davis, C.C., Edwards, M., 2014. Coagulation with hydrolyzing metal salts: Mechanisms and water quality impacts. Crit. Rev. Environ. Sci. Technol. 44, 303-347. doi:10.1080/10643389.2012.718947

DeLuca, S., Chao, A., Smallwood, C., 1983. Ames test of ferrate treated water. J. Environ. Eng. $109,1159-1167$.

Den Boef, G., Van Der Beek, H.J., Braaf, T., 1958. Absorption spectra in the visible and UV region of potassium permanganate and potassium manganate in solution and their

application to the analysis of mixtures of these compounds. Recl. des Trav. Chim. des PaysBas 77, 1064-1070.

Dentel, S.K., 1991. Coagulant control in water treatment. Crit. Rev. Environ. Control 21, 41135. doi:10.1080/10643389109388409

Duan, J., Gregory, J., 2003. Coagulation by hydrolysing metal salts. Adv. Colloid Interface Sci. 100-102, 475-502. doi:10.1016/S0001-8686(02)00067-2

Dubrawski, K.L., Cataldo, M., Dubrawski, Z., Mazumder, A., Wilkinson, D.P., Mohseni, M., 2018. In-situ electrochemical Fe(VI) for removal of microcystin-LR from drinking water: comparing dosing of the ferrate ion by electrochemical and chemical means. J. Water Health 16, wh2018187. doi:10.2166/wh.2018.187 
484 Eaton, A., Ciescerti, L., Greenberg, A., Franson, M., 2005. Standard Methods for the

485 Examination of Water and Wastewater. APHA, AWWA, WEF.

486 Faust, S.D., Aly, O.M., 1998. Chemistry of water treatment. CRC Press.

487 Feng, M., Jinadatha, C., McDonald, T.J., Sharma, V.K., 2018. Accelerated Oxidation of Organic 488 Contaminants by Ferrate(VI): The Overlooked Role of Reducing Additives. Environ. Sci. Technol. acs.est.8b03770. doi:10.1021/acs.est.8b03770

490 Goodwill, J.E., Jiang, Y., Reckhow, D.A., Gikonyo, J., Tobiason, J.E., 2015. Characterization of 491 Particles from Ferrate Preoxidation. Environ. Sci. Technol. 49, 4955-4962. 492 doi:10.1021/acs.est.5b00225

493 Goodwill, J.E., Jiang, Y., Reckhow, D.A., Tobiason, J.E., 2016. Laboratory assessment of ferrate 494 for drinking water treatment. J. Am. Water Work. Assoc. 108, 164-174. doi:http://dx.doi.org/10.5942/jawwa.2016.108.0029

496 Goodwill, J.E., Mai, X., Jiang, Y., Reckhow, D.A., Tobiason, J.E., 2016. Oxidation of 497 manganese (II) with ferrate: Stoichiometry, kinetics, products, and impact of organic 498 carbon. Chemosphere 159, 457-464. doi:10.1016/j.chemosphere.2016.06.014

499 Graham, N., Khoi, T., Jiang, J., 2010. Oxidation and Coagulation of Humic Substances by $500 \quad$ Potassium Ferrate. Water Sci. Technol. 62, 929-936.

501 Huang, X., Deng, Y., Liu, S., Song, Y., Li, N., Zhou, J., 2016. Formation of bromate during 502 ferrate(VI) oxidation of bromide in water. Chemosphere 155, 528-533.

504 Islam, A., Goodwill, J., Bouchard, R., Tobiason, J., Knocke, W., 2010. Characterization of filter 505 and media MnOx (s) surfaces and Mn removal capability. J. Am. Water Work. Assoc. 102, 506 71-83. 
Jiang, Y., Goodwill, J.E., Tobiason, J.E., Reckhow, D.A., 2016. Bromide oxidation by ferrate(VI): The formation of active bromine and bromate. Water Res. 96, 188-197. doi:10.1016/j.watres.2016.03.065

Jiang, Y., Goodwill, J.E., Tobiason, J.E., Reckhow, D.A., 2015. Effect of Different Solutes, Natural Organic Matter, and Particulate Fe(III) on Ferrate(VI) Decomposition in Aqueous Solutions. Environ. Sci. Technol. 49, 2841-2848. doi:10.1021/es505516w

Johnson, D.B., Hallberg, K.B., 2005. Acid mine drainage remediation options: A review. Sci. Total Environ. 338, 3-14. doi:10.1016/j.scitotenv.2004.09.002

Johnson, P., Amirtharajah, A., 1983. Ferric chloride and alum as single and dual coagulants. J. Am. Water Works Assoc. 75, 232-239.

Knocke, W., Van Benschoten, J., Kearney, M., Soborski, A., Reckhow, D.A., 1991. Kinetics of Manganese and Iron Oxidation by Potassium Permanganate and Chlorine Dioxide. J. Am. Water Work. Assoc. 83, 80-87.

Knocke, W.R., Hoehn, R.C., Sinsabaugh, R.L., 1987. Using alternative oxidants to remove dissolved manganese from waters laden with organics. J. Am. Water Works Assoc. 79, 7579.

LaBar, J., Nairn, R., Strevett, K., Strosnider, W., Morris, D., Neely, C., Garrido, A., Kauk, K., 2011. Stream water quality improvements after installation of a passive treatment system, in: Proceedings of the American Society of Mining and Reclamation. Pittsburgh, PA, pp. 525-535. doi:10.21000/JASMR11010525

Lee, Y., Kissner, R., von Gunten, U., 2014. Reaction of ferrate(VI) with ABTS and self-decay of ferrate(VI): kinetics and mechanisms. Environ. Sci. Technol. 48, 5154-5162. doi:10.1021/es500804g 
530 Lee, Y., Zimmermann, S.G., Kieu, A.T., Von Gunten, U., 2009. Ferrate (Fe(VI)) application for

531 municipal wastewater treatment: A novel process for simultaneous micropollutant oxidation

532 and phosphate removal. Environ. Sci. Technol. 43, 3831-3838. doi:10.1021/es803588k

533 Lv, D., Zheng, L., Zhang, H., Deng, Y., 2018. Coagulation of colloidal particles with ferrate(vi).

534 Environ. Sci. Water Res. Technol. 4, 701-710. doi:10.1039/c8ew00048d

535 Ma, J., Liu, W., 2002. Effectiveness of ferrate (VI) preoxidation in enhancing the coagulation of $536 \quad$ surface waters. Water Res. 36, 4959-4962.

537 Monzyk, B.F., Rose, J.K., Burckle, E.C., Smeltz, A.D., Rider, D.G., Cucksey, C.M., Clark, T.O., 538 2013. Method for producing ferrate (V) and/or (VI). US8449756B2.

539 Morgan, J.J., Stumm, W., 1964. Colloid-Chemical Properties of Manganese Dioxide. J. Colloid $540 \quad$ Sci. $19,347-359$.

541 Murshed, M., Rockstraw, D.A., Hanson, A.T., Johnson, M., 2003. Rapid oxidation of sulfide 542 mine tailings by reaction with potassium ferrate. Environ. Pollut. 125, 245-253.

543 doi:10.1016/S0269-7491(03)00052-6

544 Neculita, C.M., Rosa, E., 2019. A review of the implications and challenges of manganese 545 removal from mine drainage. Chemosphere 214, 491-510.

546 doi:10.1016/j.chemosphere.2018.09.106

547 Ockerman, L., Schreyer, J., 1951. Preparation of Sodium Ferrate(VI) 72, 5478.

548 Pennsylvania Department of Environmental Protection (PA DEP). Title 25 Environmental $549 \quad$ Protection. 1998. Chapter 87.102

550 Reckhow, D.A., Knocke, W.R., Kearney, M.J., Parks, C.A., 1991. Oxidation Of Iron And

551 Manganese By Ozone. Ozone Sci. Eng. 13, 675-695.

$552 \quad$ doi:10.1080/01919512.1991.10555708 
553 Rush, J.D., Zhao, Z., Bielski, B.H.J., 1996. Reaction of Ferrate (VI)/Ferrate (V) with Hydrogen 554 Peroxide and Superoxide Anion - a Stopped-Flow and Premix Pulse Radiolysis Study. Free $555 \quad$ Radic. Res. 24, 187-198.

556 Sharma, V., 2002. Potassium ferrate (VI): an environmentally friendly oxidant. Adv. Environ. Res. 2002, 143-156.

Sharma, V.K., Chen, L., Zboril, R., 2016. Review on High Valent FeVI (Ferrate): A Sustainable Green Oxidant in Organic Chemistry and Transformation of Pharmaceuticals. ACS Sustain. Chem. Eng. 4, 18-34. doi:10.1021/acssuschemeng.5b01202

Sharma, V.K., Smith, J.O., Millero, F.J., 1997. Ferrate(VI) Oxidation of Hydrogen Sulfide. Environ. Sci. Technol. 31, 2486-2491. doi:10.1021/es960755z

Singer, P., Stumm, W., 1970. Acidic Mine Drainage: The Rate-Determining Step. Science (80) $167,1121-1123$.

Skousen, J., Zipper, C.E., Rose, A., Ziemkiewicz, P.F., Nairn, R., McDonald, L.M., Kleinmann, R.L., 2017. Review of Passive Systems for Acid Mine Drainage Treatment. Mine Water Environ. 36, 133-153. doi:10.1007/s10230-016-0417-1

Song, Y., Deng, Y., Jung, C., 2016. Mitigation and degradation of natural organic matters (NOMs) during ferrate(VI) application for drinking water treatment. Chemosphere 146, 145-153. doi:10.1016/j.chemosphere.2015.12.001

Stanford, C., Jiang, J.Q., Alsheyab, M., 2010. Electrochemical production of ferrate (Iron VI): 
impact the Rio Pilcomayo headwaters. Environ. Earth Sci. 71, 3223-3234. doi:

Stumm, W., Morgan, J.J., 2012. Aquatic Chemistry: Chemical Equilibria and Rates in Natural Waters. John Wiley \& Sons.

Stumm, W., O’Melia, C., 1968. Stoichiometry of Coagulation. J. Am. Water Works Assoc. 60, $514-539$.

Sun, J., Tang, C., Wu, P., Strosnider, W.H.J., Han, Z., 2013. Hydrogeochemical characteristics of streams with and without acid mine drainage impacts: a paired catchment study in karst geology, SW China. J. Hydro. 504, 115-124. doi:10.1016/j.jhydrol.2013.09.029

Thompson, G., Ockerman, L., Schreyer, J., 1951. Preparation and purification of Potassium Ferrate VI. J. Am. Chem. Soc. 73, 1379-1381. doi:10.1021/ja01147a536

Tobiason, J.E., Bazilio, A., Goodwill, J., Mai, X., Nguyen, C., 2016. Manganese Removal from Drinking Water Sources. Curr. Pollut. Reports 1-10. doi:10.1007/s40726-016-0036-2

Tobiason, J.E., Knocke, W.R., Goodwill, J., Hargette, P., Bouchard, R., Zuravnsky, L., 2008. Characterization and Performance of Filter Media for Manganese Control. Water Research Foundation, Denver, CO.

Van Benschoten, J.E., Edzwald, J.K., 1990. Chemical aspects of coagulation using aluminum salts - I. Hydrolytic reactions of alum and polyaluminum chloride. Water Res. 24, 1519Stud. Environ. Sci.

597 Watzlaf, G. Schroeder, K., Kleinmann, R., Kairies, C., Narin, R., 2004. The passive treatment of 598 coal mine drainage, Laboratory Report DOE/NETL-2004/1202, Pittsburgh, PA. 
599 Wolkersdorfer, C., Bowell, R., 2004a. Contemporary reviews of mine water studies in Europe,

600 Part 1. Mine Water Environ. 23, 162-182. doi:10.1007/s10230-004-0060-0

601 Wolkersdorfer, C., Bowell, R., 2004b. Contemporary reviews of mine water studies in Europe,

602 Part 2. Mine Water Environ. 24, 2-37. doi: 10.1007/s10230-005-0068-0

603 Wolkersdorfer, C., Bowell, R., 2004c. Contemporary reviews of mine water studies in Europe,

604 Part 3. Mine Water Environ. 24, 58-76. doi: 10.1007/s10230-005-0074-2

605 Yates, B.J., Zboril, R., Sharma, V.K., 2014. Engineering aspects of ferrate in water and

606 wastewater treatment - a review. J. Environ. Sci. Heal. Part A 49, 1603-1614.

607 doi:10.1080/10934529.2014.950924

608 Younger, P.L, Banwart, S.A., Hedin, R.S., 2002. Mine Water: Hydrology, Pollution,

609 Remediation. Kluwer Academic Publishers

610 Yu, M.R., Chang, Y.Y., Keller, A.A., Yang, J.K., 2013. Application of ferrate for the treatment

611 of metal-sulfide. J. Environ. Manage. 116, 95-100. doi:10.1016/j.jenvman.2012.12.009

612 Zheng, L., Deng, Y., 2016. Settleability and characteristics of ferrate(VI)-induced particles in

613 advanced wastewater treatment. Water Res. 93, 172-178. doi:10.1016/j.watres.2016.02.015

614

615 


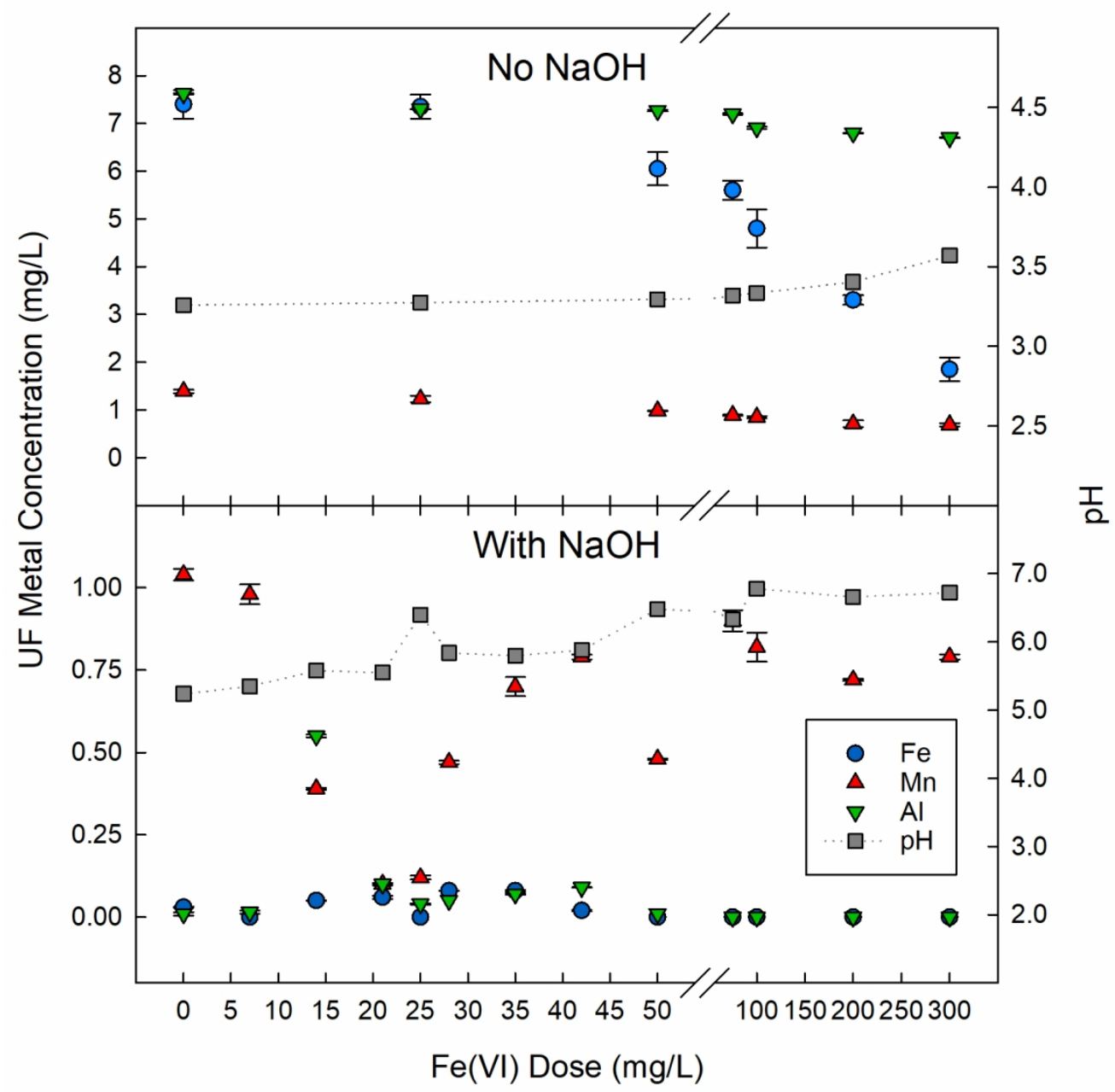

Fig 1. Metal concentrations after $30 \mathrm{kDa}$ membrane ultrafiltration (UF) and $\mathrm{pH}$ following ferrate oxidation of acid mine drainage with and without $\mathrm{NaOH}$ co-addition.

$147 \times 148 \mathrm{~mm}(300 \times 300$ DPI) 


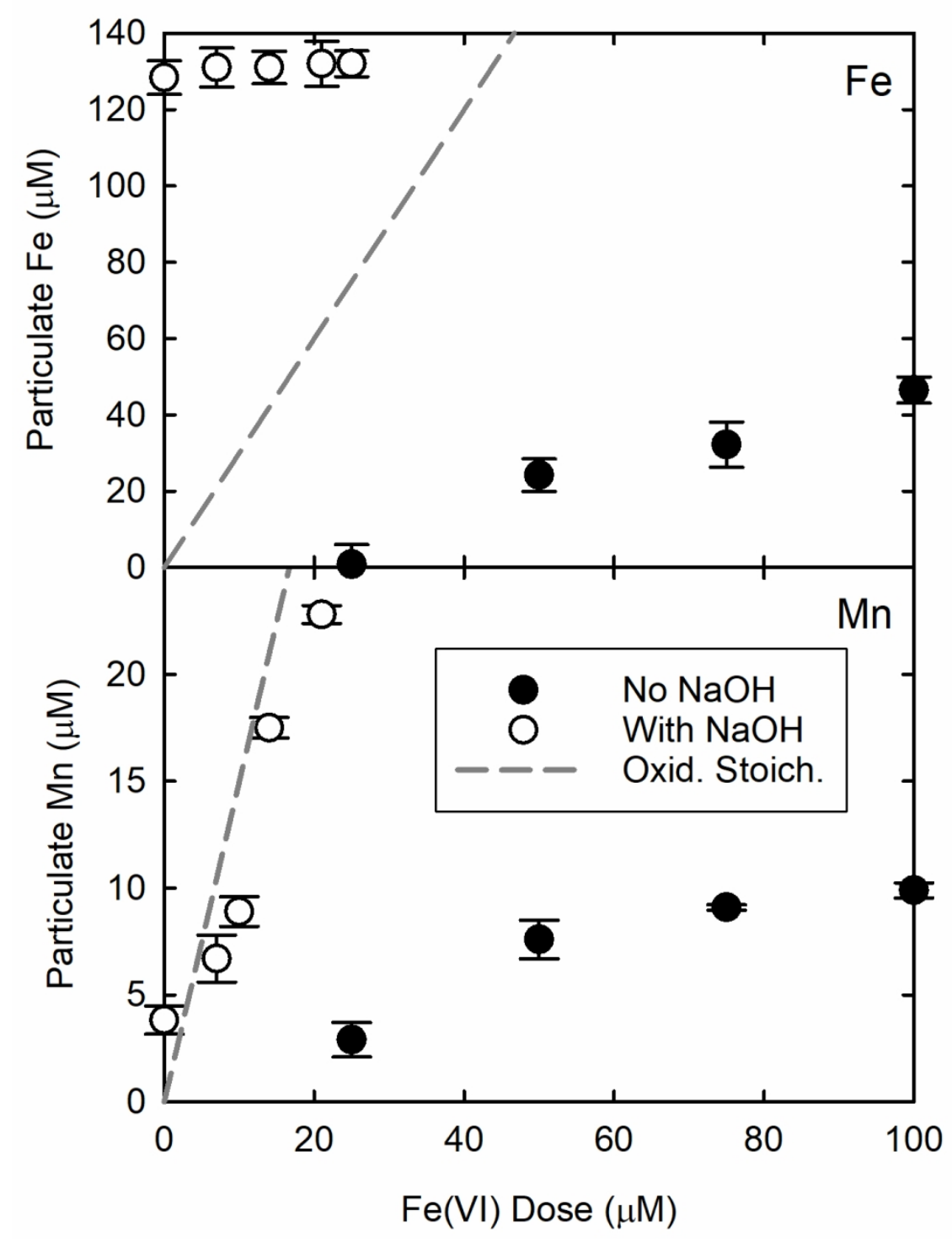

Fig 2. Molar concentrations of precipitated $\mathrm{Fe}$ and $\mathrm{Mn}$ for a given $\mathrm{Fe}(\mathrm{VI})$ dose in both with and without 6.8 $\mathrm{mL}$ of $50 \% \mathrm{NaOH}$ solution conditions. Expected Fe oxidation stoichiometry of $3 \mathrm{Fe}(\mathrm{II})$ : $\mathrm{Fe}(\mathrm{VI})$ from Lee et al., 2014. Expected Mn oxidation stoichiometry of $3 \mathrm{Mn}(\mathrm{II}): 2 \mathrm{Fe}(\mathrm{VI})$ from Goodwill et al., 2016.

$114 \times 156 \mathrm{~mm}(300 \times 300 \mathrm{DPI})$ 


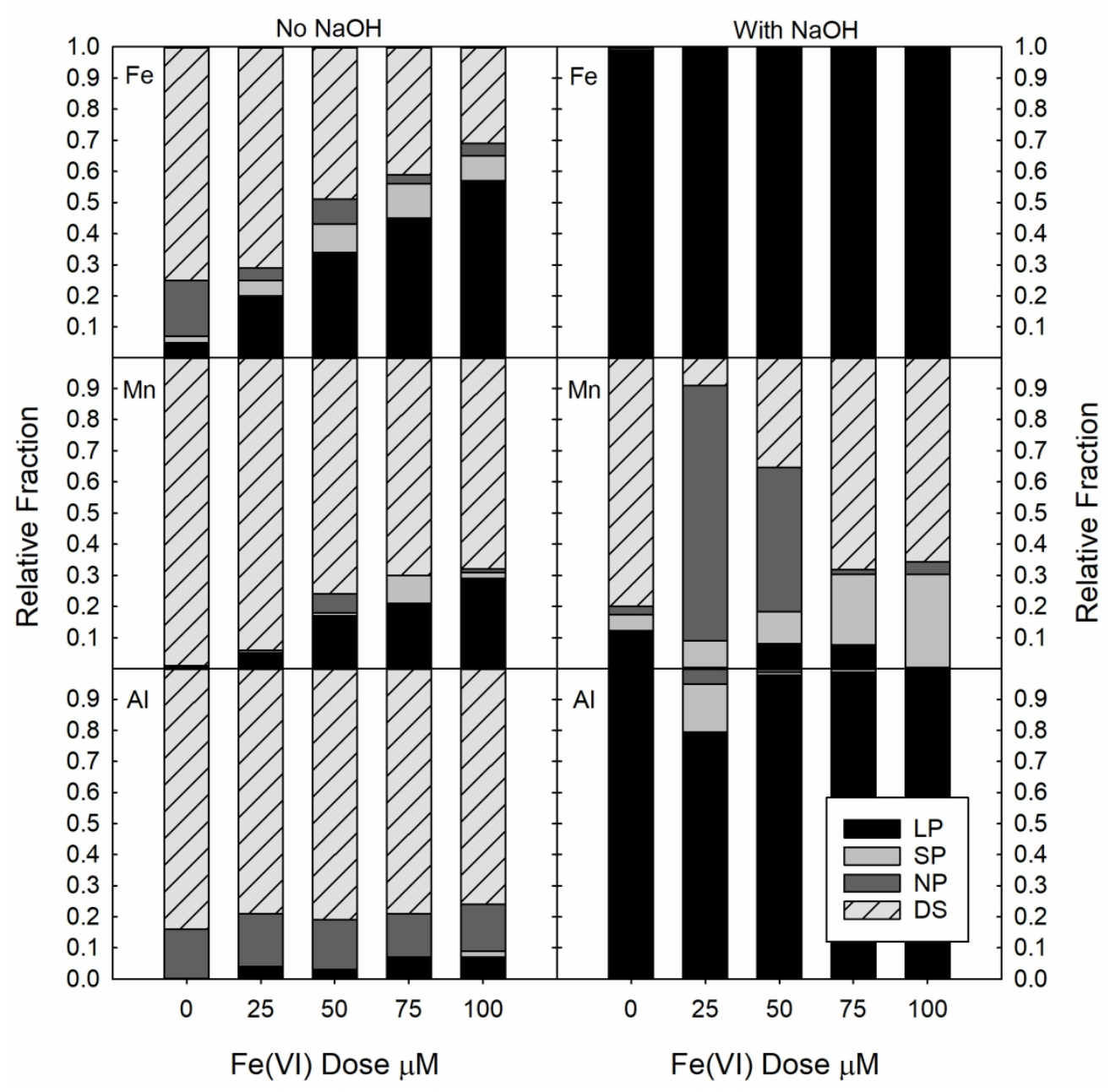

Fig. 3. Size fractionation of metal particles resulting from the oxidation of acid mine drainage by ferrate, on a mass of metal basis, with and without the co-addition of $6.8 \mathrm{~mL}$ of $50 \% \mathrm{NaOH}$ solution. (LP = Large Particles, $\mathrm{SP}=$ Small Particles, $\mathrm{NP}=$ Nanoparticles, $\mathrm{DS}=$ Dissolved $)$. 


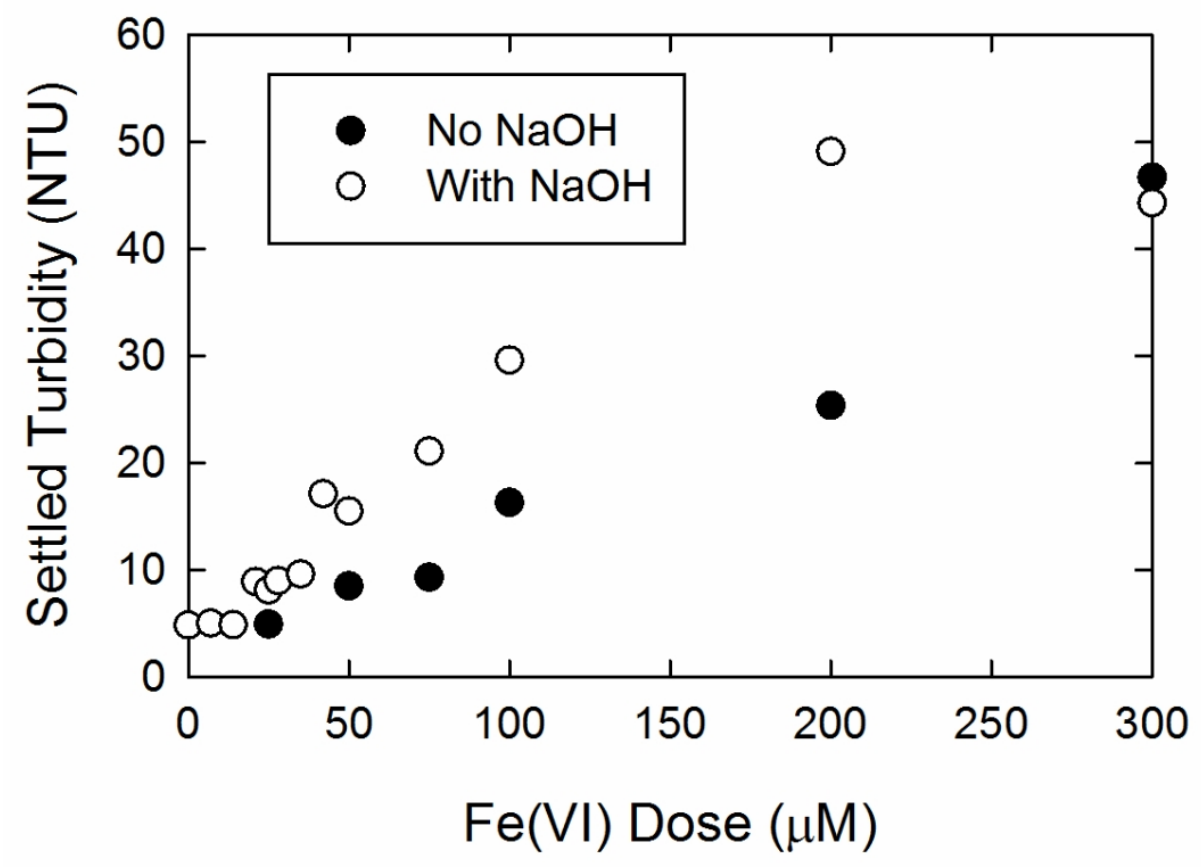

Fig 4. Turbidity of AMD solutions following various ferrate dosages, with and without the co-addition of $\mathrm{NaOH}$.

$103 \times 79 \mathrm{~mm}(300 \times 300 \mathrm{DPI})$ 